\title{
Analysis of the Urban Fabric Using Land Use and Development Rules
}

\author{
Alexandr Nikolaevich Gushchin ${ }^{1}$, Fedor Alexandrovich Gushchin ${ }^{2} \&$ Sergei Iosifivich Sanok ${ }^{2}$ \\ ${ }^{1}$ The Urban Institute, Ural State Academy of Architecture and Arts, Ekaterinburg, Russian Federation \\ ${ }^{2}$ The Department of Urban Planning, Ural State Academy of Architecture and Arts, Ekaterinburg, Russian \\ Federation \\ Correspondence: Alexandr Nikolaevich Gushchin, Ural State Academy of Architecture and Arts, 23 St. Karl \\ Liebknecht, 620075 Ekaterinburg, Russian Federation. Tel: 7-908-903-9260. E-mail: alexanderNG@yandex.ru
}

Received: December 15, 2014

Accepted: December 20, 2014

Online Published: March 25, 2015

doi:10.5539/mas.v9n5p50

URL: http://dx.doi.org/10.5539/mas.v9n5p50

\begin{abstract}
A widespread model for urban systems development description in the form "frame and fabric" was proposed by the Soviet urban planner Gutnov A. E. as an alternative to a functional approach, used to control the territory development. While developing the model, Gutnov posed the problem of the transition from a functional description of the destination area to description of the intensity of the processes occurring in the territory. This article develops and deepens the approach based on the study of the intensity of the processes occurring in the territory by means of land use and development rules. The research method as before consists of the following steps: a uniform grid covers the researched area (city). Then a frequency histogram is created for the researched attribute. Then, based on the histogram, contour line maps of the researched attribute are created. This paper takes the following as the researched attributes: 1) the share of residential and recreational zones in relation to the total number of urban land use zones falling within the grid cell; 2) The share of restrictions on use of residential and recreational zones in relation to the total number of restrictions on use forth in the urban planning regulations all land use zones falling into the grid cells.

Eight cities of Russia were analysed and provided with created contour line maps. Based on the analysis, average quantitative characteristics for the researched attributes are set. It was found that the entire considered sample is divided into two groups: the cities with a single spatial axis with respect to which residential and recreational areas are further grouped, and the cities with no single direction. Meaningful interpretation of this observation is provided.
\end{abstract}

Keywords: land use and development rules, land development intensity, "frame-fabric" model, mathematical and statistical analysis, urban planning, urban studies

\section{Introduction}

Land use and development rules are incorporated into the Urban Planning Code'2004. They govern the regulation procedures of land use and development for the settlement territory by the local authorities and urban zoning procedures. In turn, urban zoning and regulation of the settlements territory development, which principles are provided by the Rules, govern the ability to transform the environment, engaging all the stakeholders in the process, and, ultimately, ability to restructuring the entire urban system under the influence of goal-setting by the free enterprising. In this regard, it is necessary to research the new possibilities and features of the urban systems formation and the theoretical description of urban development processes due to the use of Land use and development rules (LUDR).

In the book "The Evolution of Urban Planning" (Gutnov, 1984), a prominent Soviet urban planner, Gutnov A. E., posed the problem of the transition from the description based on the functional approach to the description of a new type, namely to description of the territory development intensity as a reflection of the maturity and level of urban planning system development. Mathematised formulation of the city description problem by the degree of the territory development intensity is the following - "Identifying the relationships between the basic properties of the urban area $\mathrm{F}, \mathrm{D}, \mathrm{T}$, where $\mathrm{F}$ is the functional use type, $\mathrm{D}$ is the development intensity, and $\mathrm{T}$ is the placement (positional data)" (ibid p.119). In other words, it is a question of establishing relationships in the form of

$$
f=f(F, D, T)
$$


Later, relationship (1) resulted in the "frame and fabric" model. The cited paper by Gutnov was an attempt to combine the two different traditions of basic urban systems study. On the bottom side, there is the tradition of urban planning, originating from the famous paper by Clark, dedicated to the study of the urban population distribution density depending on the distance. Clark's formula (like his approach) for quantitative pattern of spatial changes in the density of the urban population is confirmed in the works of other devotees of using mathematical and statistical methods for the analysis of urban systems. The information can be learned in the reviews (J. McDonald, 1989). In the future, quantitative ratios have been used in the context of applied sciences: transport geography (B. Liddle, 2013), economics (N. Karathodoroua, D. J. Grahama, R. B. Noland, 2010) et cetera.

In contrast to this tradition, the Soviet urban school focused on the use of functional approach to the territory development, which was reflected in the works of the founders and followers of the traditions: Belousov, V. I., Smolyar, I. M., Sdobnov, Yu. A., Vladimirov, V. V., Lavrov, V. A., Kudryavtsev, O. K., Bocharov, Yu. P., Kogan, L. B. (Smolyar, I. M., 2001; Vladimirov, V. V., 1999). The main efforts in this approach are devoted to the problem of optimal mutual accommodation of areas with defined functional purpose. Functional areas as per the definition by the Urban Planning Code of the Russian Federation are zones for which the territorial planning documents define boundaries and functionality. The Urban Development Code does not define types and composition of the functional areas. Residential, recreational, industrial and others zones are distinguished.

It is interesting that despite all the differences of the approaches, the "frame and fabric" model is recognized and used in both traditions. The example of mathematical and statistical analysis use is the work on the construction of various indices within the "frame and fabric" model (Yu, H. T. 2005). The term of "urban fabric thinning" is also well-known. The present work is an attempt to return to the original formulation of the problem in the statement by Gutnov in the form of formula (1), but on a new basis - on the use of the possibilities inherent in the Land use and development rules. In the first paper of this cycle (Gushchin, F. A., Gushchin, A. N., Sanok, S. I., 2012) we have shown that the measure for the intensity of the territory development (D) can be represented as the number of permitted kind of use of the territory (restrictions on use), recorded in urban planning regulations applied to each land use zone. The proofs are represented as contour line maps for the number of restrictions on use of urban land use zones for a total number of restrictions of large and major cities. Further, we studied the development of institonal (social and business) (Gushchin, F. A., Gushchin, A. N., Sanok, S. I., 2013) and industrial zones (Gushchin, F. A., Gushchin, A. N., Sanok, S. I., 2013). The present work is the deepening of the proposed approach and is dedicated to the study of the spatial distribution in case of residential and recreational zones. The importance of studying the spatial distribution of residential and recreational land use zones is because, unlike the industrial and institutional zones creating a frame of social and economic activity at the territories, residential and recreational land use zones are a fabric "stretched" on this frame. Gutnov A. E. in his "frame and fabric" model refers to the fabric as to a "material substratum" of the urban planning system. Thus, his article analyses the spatial structure of the urban fabric.

\section{Method}

The method of research is completely analogous to that used earlier (Gushchin, F. A., Gushchin, A. N., Sanok, S. I., 2012). Briefly, it involves the following steps: the area of the researched city is covered with a uniform rectangular grid. Grid pitch is chosen so that each cell of the grid covers several land use zones. More precisely, their amount shall be sufficient to be able to use methods of mathematical statistics. Then, the frequency of instances when the researched attribute gets into a grid cell is counted and frequency histograms are created. The researched attributes include the share of land use zones - residential and recreational - in relation to the total number of urban land use zones falling within the grid cell; and the number of restrictions on use forth in the planning regulations pertaining to residential and recreational zones, relatively to the total the number of restrictions on use of urban land use zones falling within the grid cell. Further, histogram approximation using a piecewise linear surface was carried out and contour line maps of the researched attribute level were created. The resulting contour lines were exported to a graphics package. They were smoothed using the method of splines. 


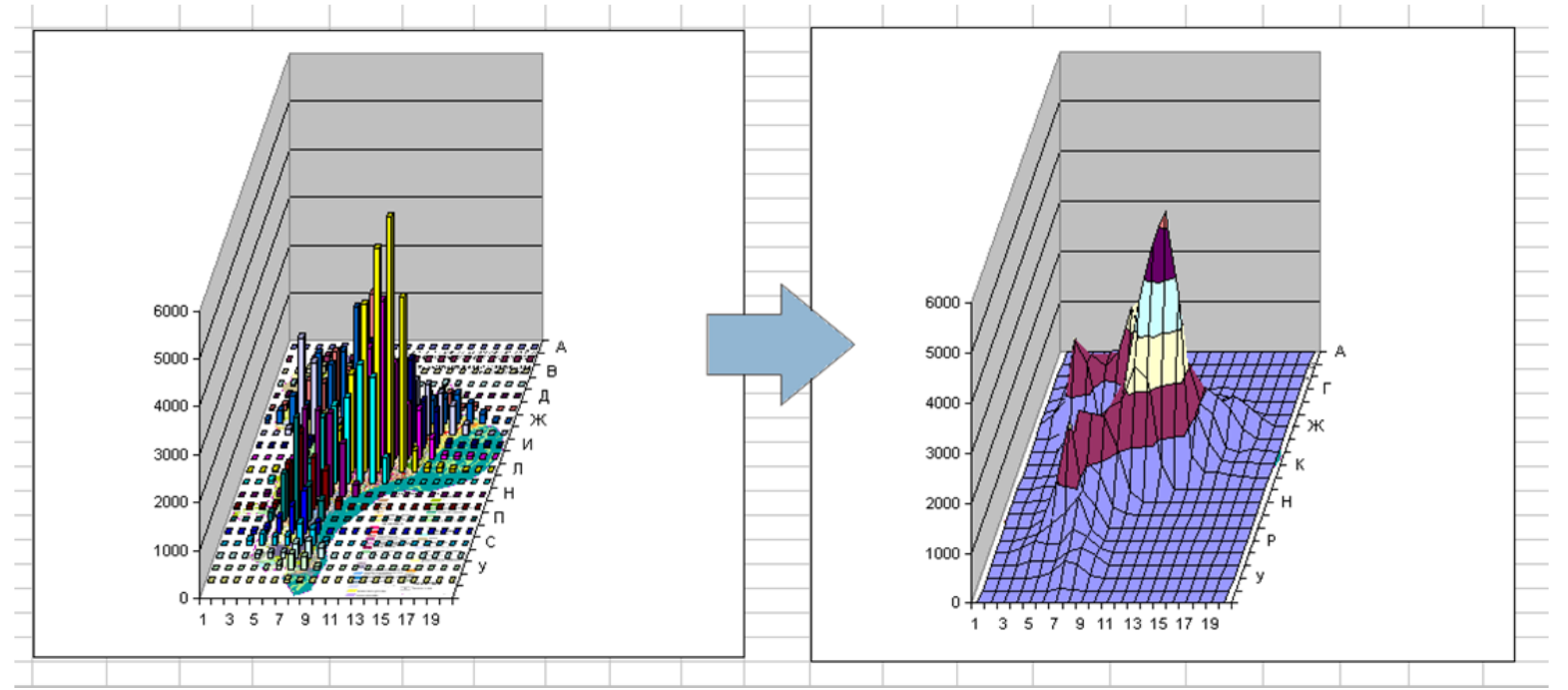

Figure 1. Histogram approximation of uses using a piecewise linear surface

The choice of the researched attributes is based on the following circumstances. Firstly, the selection of the basic document - the Land use and development rules - is because the rules are the only normative document of the entire documents corpus of territorial planning and urban zoning. In addition, the Urban Planning Code in Art. 30 requires the creation of "...conditions to attract investment, including by allowing the selection of the most effective types of permitted use of land and capital construction projects" as one of the purposes of the Rules. Thus, the Land use and development rules are a document that directly determines the behaviour of the investor determining the intensity of land development. Therefore, the first researched attribute - the share of urban residential and recreational land use zones to the total share - really characterizes the share of "material substratum" of the urban planning system, namely the state and the spatial structure of the urban fabric. More complex feature is the second researched attribute. According to the Urban Planning Code, the planning regulations consist of three parts: the list of the types of permitted uses of real estate (restrictions on use), the list of types of conditionally permitted use, and the list of additional uses. The list of permitted uses of real estate is a list of real estate that can be built in the area of urban land use zone with minimal coherence. Therefore, the second researched attribute - the ratio of restriction on use for urban land use zones of residential and recreational zones to the total number of restrictions on use in all land use zones - is a more subtle feature of the urban fabric. This feature captures urban fabric formation trends.

Finally, the choice of cities for which the method described and constructed contour line maps were applied. The choice was determined solely by the two factors: a) the city shall be large enough so that it was possible to get a histogram of frequencies (see Figure 1), b) there shall be the availability and quality of raw data - Land use and development rules.

\section{Results}

Figures 2 and 3 show the calculated contour line maps of residential and recreational areas for Yekaterinburg (Yekaterinburg LUDR, 2004). 


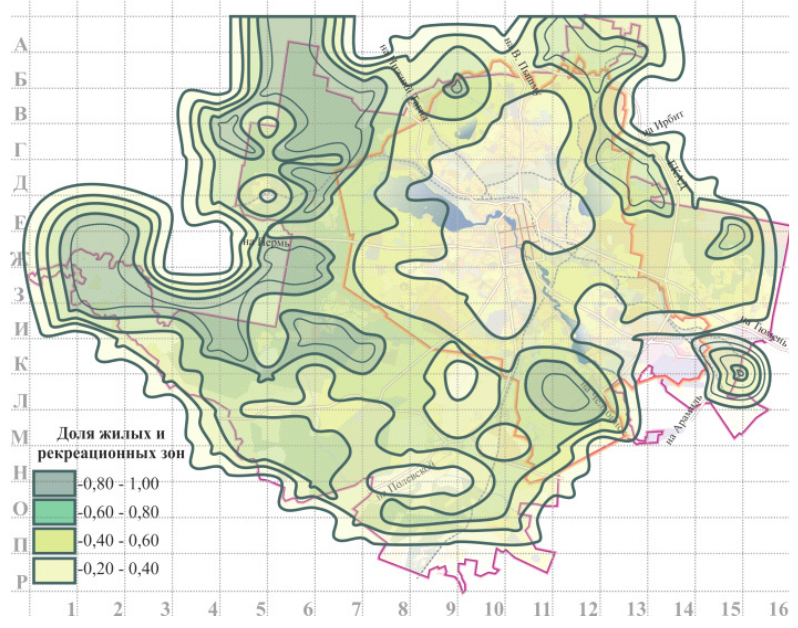

Figure 2. Contour line maps of share of residential and recreational zones to the total number of land use zones for Yekaterinburg

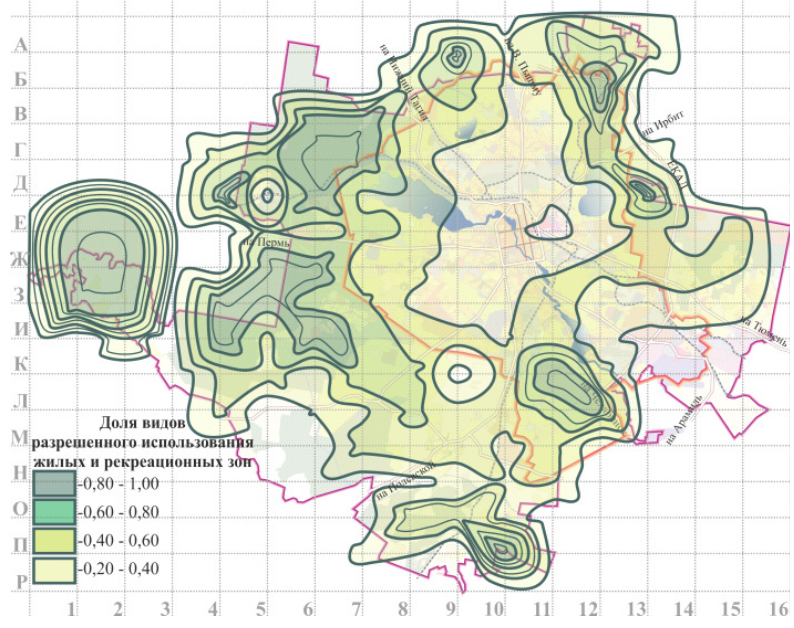

Figure 3. Contour line maps of share of residential and recreational restrictions on use to the total number of restrictions on use for urban zones in Yekaterinburg

Structure of contour lines for the number of residential and recreational zones for Yekaterinburg in Figure 2 shows: a) a marked tendency to the imposition of residential zones on the outskirts of the city, b) polynuclear structure of the spatial distribution of residential and recreational areas, and c) grouping mainly in the north-west direction. Spatial unevenness in building up the urban "fabric" suggests that the major axis of Yekaterinburg's urban frame is arranged in the direction "north-south", and the urban "fabric" is being formed perpendicular to this axis. Contour line maps of restrictions on use shares of residential and recreational land use zones, shown in Figure 3, is similar in its structure to contour line maps of share of residential and recreational zones, indicating the stability of the spatial configuration of the areas.

Figures 4 and 5 show the results for the city of Kaliningrad (Kaliningrad LUDR, 2014).

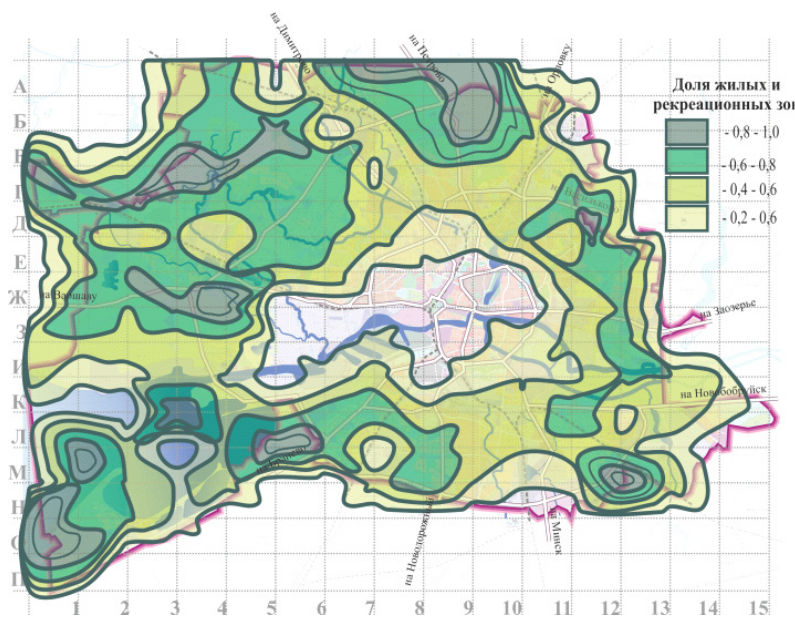

Figure 4. Contour line maps of share of residential and recreational zones to the total number of land use zones for Kaliningrad

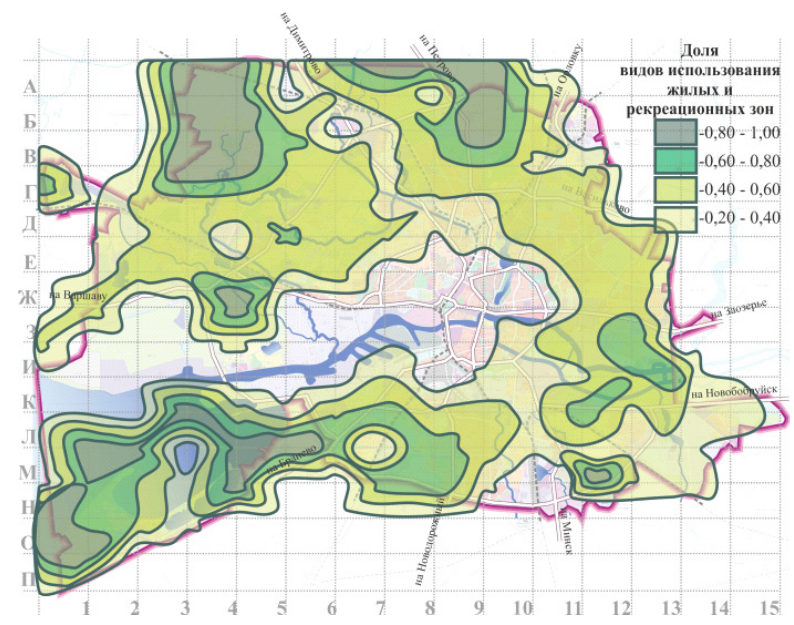

Figure 5. Contour line maps of share of residential and recreational restrictions on use to the total number of restrictions on use for urban zones in Kaliningrad

Contour line map shown in Figure 4 for Kaliningrad, demonstrates trends similar to Yekaterinburg: there are polynuclear spatial structure and trend for the imposition of residential areas on the outskirts of the city. However, 
there are two distinctions from Yekaterinburg (Figure 1): a) residential and recreational areas on the outskirts are distributed more evenly, b) "islands" of residential and recreational areas are denser, - the proportion of residential and recreational areas is higher relatively to the background. Also, the spatial axis in the direction of "north-west south-east" is observed, and the islands of residential and recreational areas are located perpendicular to it. Spatial structure of contour line map for restrictions on use share of residential and recreational land use zones for Kaliningrad (Figure 5) is similar to the spatial structure of contour lines of residential and recreational zones share. It witnesses the sustainability of urban "frame" and the existing balance between the "frame" and the "fabric".

Figures 6 and 7 show the results for the city of Omsk (Omsk LUDR, 2008). In Omsk, residential and recreational areas are also located on the periphery of the city, but urban "fabric" permeates all urban planning space. The spatial structure of residential and recreational areas remains polynuclear. It is still possible to allocate space in the direction of "north-west south-east" perpendicular which fabric is created. Earlier, in the analysis of industrial land use zones structure (Gushchin, F. A., Gushchin, A. N., Sanok, S. I., 2013); we noted that Omsk is characteristic with the formation of the peripheral belt of industrial zones. This spatial arrangement of zones can be called inverse, because it generates traffic flows not from the periphery to the centre, but rather from the centre to the periphery (the place of residence to the place of work).

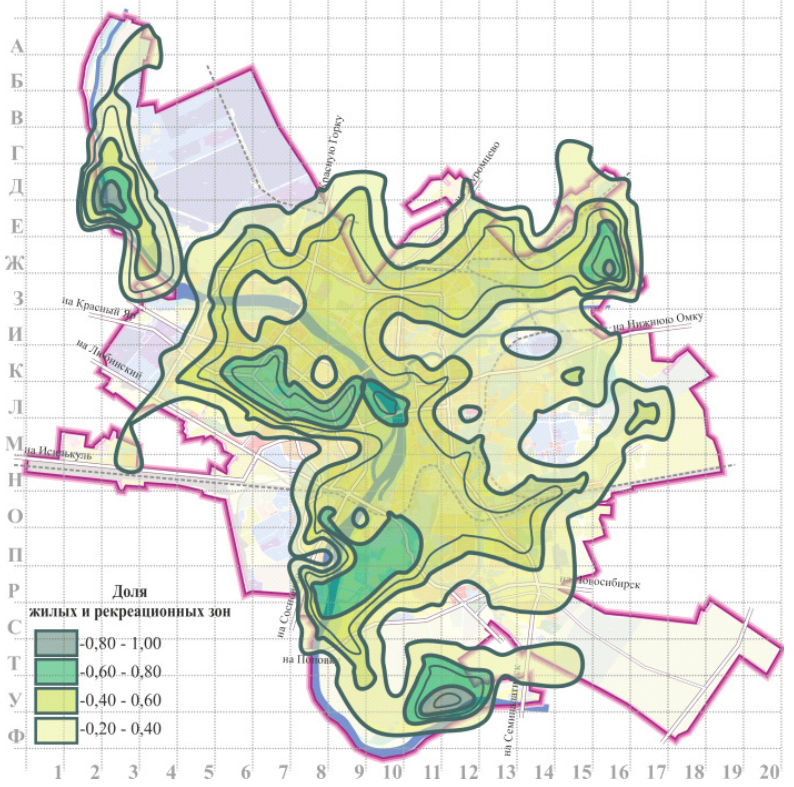

Figure 6. Contour line maps of share of residential and recreational zones to the total number of land use zones for Omsk

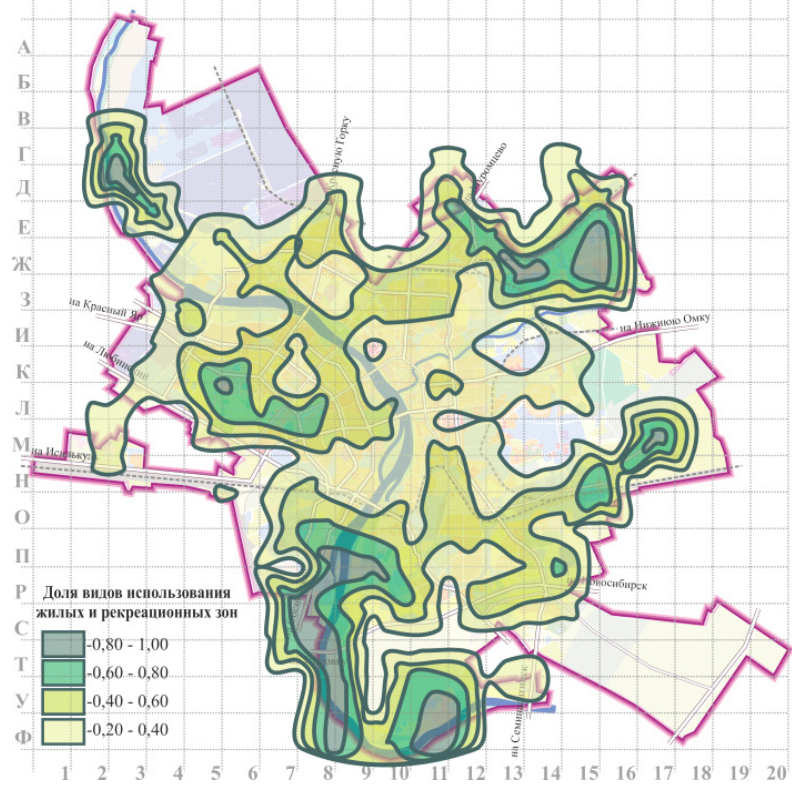

Figure 7. Contour line maps of share of residential and recreational restrictions on use to the total number of restrictions on uses for urban zones in Omsk

Figure 7 shows a map of contour lines of restrictions on use share of residential and recreational zones shows the different dynamics of the process - the tendency to the formation of a peripheral area of residential and recreational areas and enhance the urban fabric in the direction perpendicular to the main axis of the frame, extending in the "north-south west east".

Figures 8 and 9 show the results for the city of Perm (Perm LUDR, 2007). 


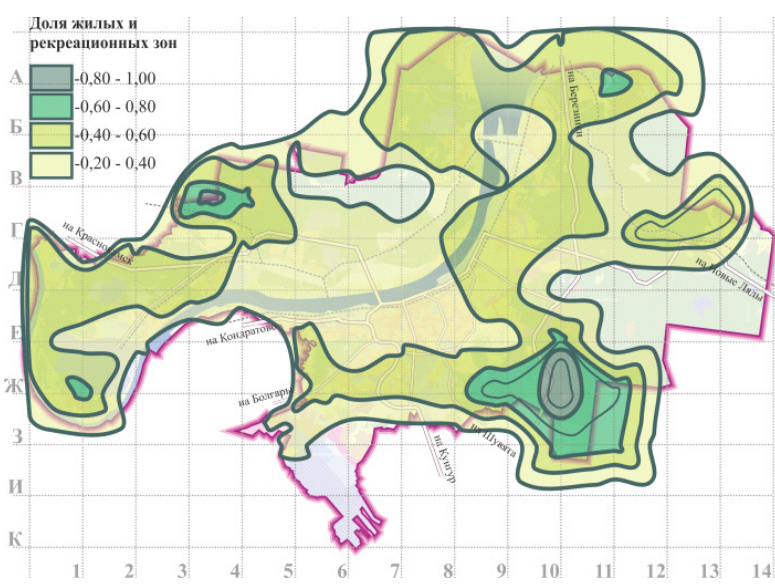

Figure 8. Contour line maps of share of residential and recreational zones to the total number of land use zones for Perm

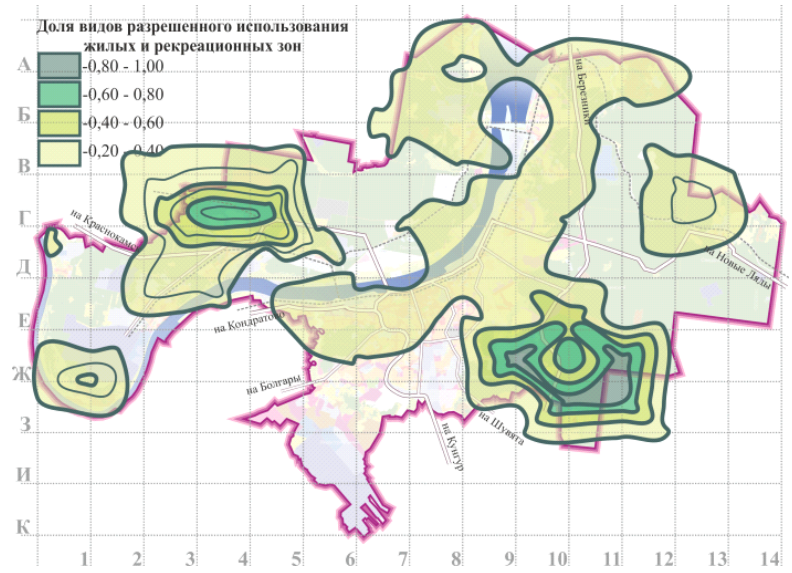

Figure 9. Contour line maps of share of residential and recreational restrictions on use types to the total number of restrictions on use for urban zones in Perm

Figure 8 provides polynuclear structure of residential and recreational areas pronounced much less, the spatial arrangement of residential and recreational areas are uniform, urban "fabric" permeates a significant part of the urban planning space. Nevertheless, it can be said that the urban fabric is also formed in the direction perpendicular to the main planning frame axis, given by the natural communication direction - the river. The spatial structure of the contour lines restrictions on use for residential and recreational zones is completely similar to the above picture shown in Figure 9.

Figures 10 and 11 show the results for the city of Ryazan (Ryazan LUDR, 2008).

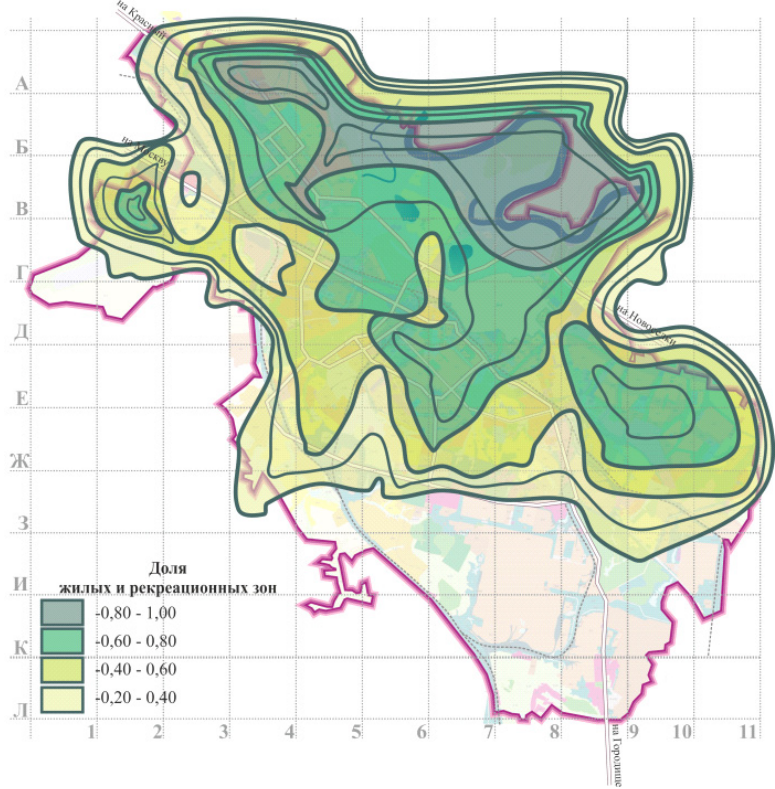

Figure 10. Contour line maps of share of residential and recreational zones to the total number of land use zones for Ryazan

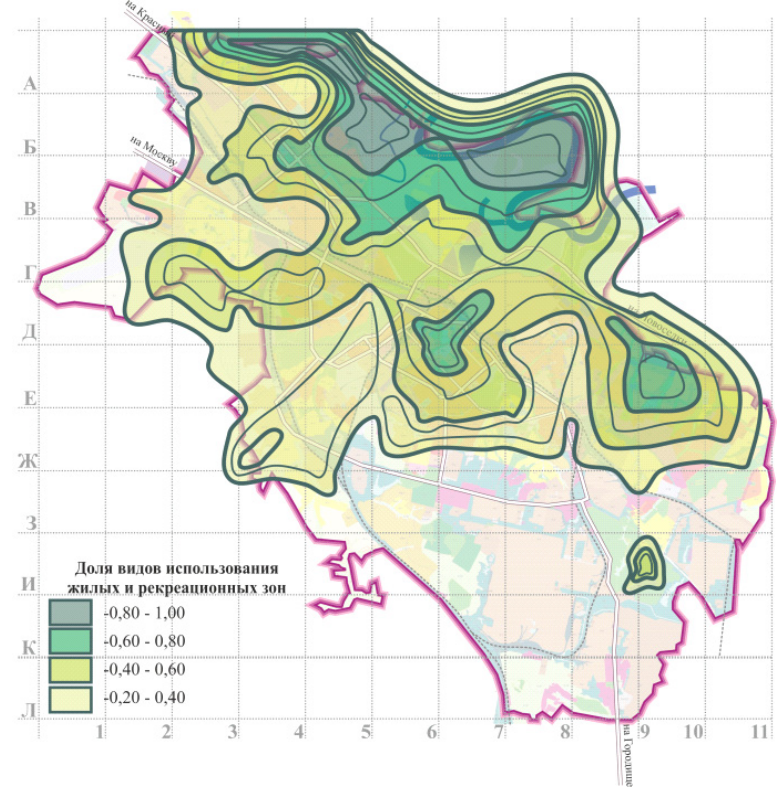

Figure 11. Contour line maps of share of residential and recreational restrictions on use to the total number of restrictions on use for urban zones in Ryazan 
Figure 10 shows that the residential and recreational areas in general form the urban planning space. Polynuclear spatial structure of the urban fabric is blurred and is more clearly visible on the contour line map of restrictions on use, characteristic of the residential and recreational land use zones; Figure 11 shows the same but in relation to the total number of restrictions on use. The last exhibits a tendency to form a peripheral area in the direction of "north-west south-east".

Figures 12 and 13 show the results for the city of Saratov (Saratov LUDR, 2008). Figure 12 demonstrates the spatial structure of residential and recreational areas as polynuclear, which is also built up perpendicular to the main planning axis, located in the direction "north-south-west". However, the direction of this axis is not directly related to the natural communication direction development - the river. In addition to the large planning axis, another one can be allocated - it is smaller and is located in the direction of "centre-north-west". Contour line map of share of residential and recreational zones restrictions on use (Figure 13) has a similar spatial structure.

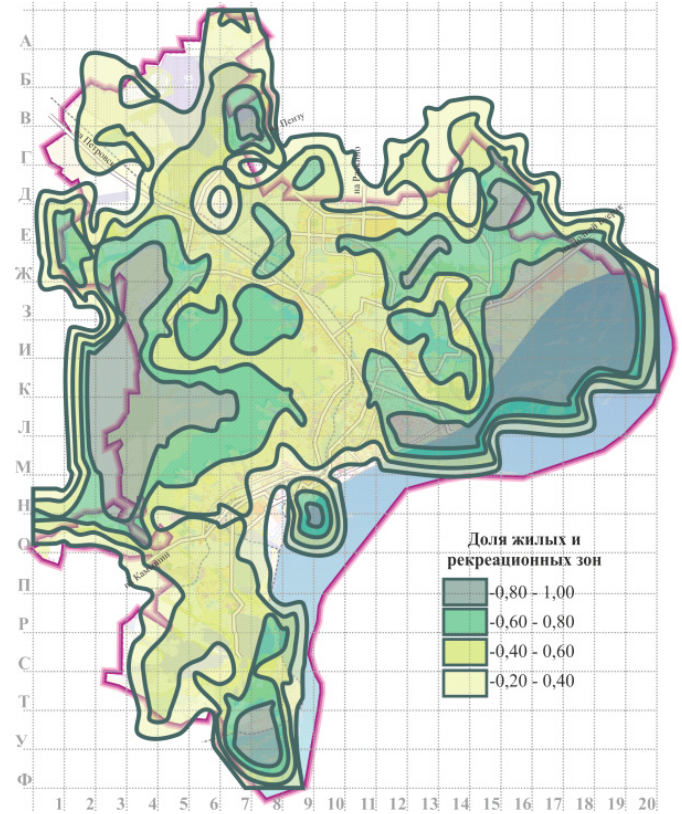

Figure 12. Contour line maps of share of residential and recreational zones to the total number of land use zones for Saratov

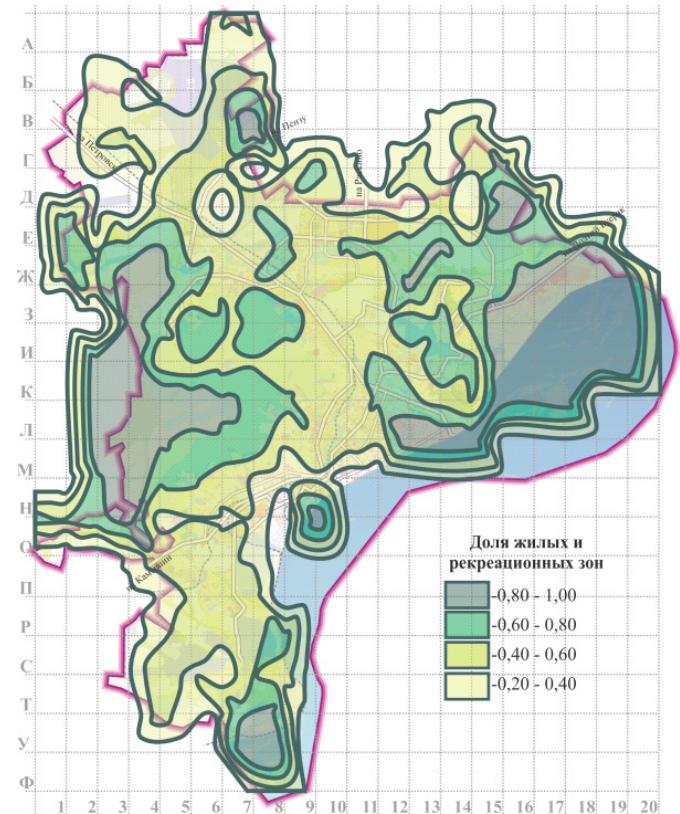

Figure 13. Contour line maps of share of residential and recreational restrictions on use to the total number of restrictions on use for urban zones in Saratov

Figures 14 and 15 show the results for the city of Smolensk (Smolensk LUDR, 2010).

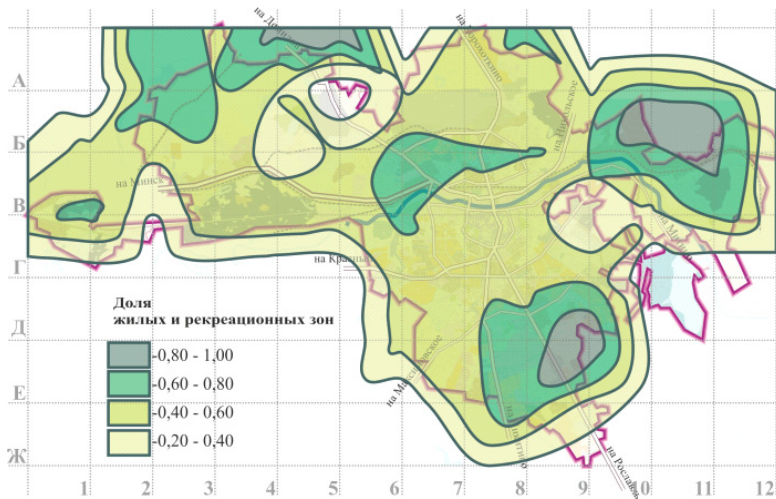

Figure 14. Contour line maps of share of residential and recreational zones to the total number of land use zones for Smolensk

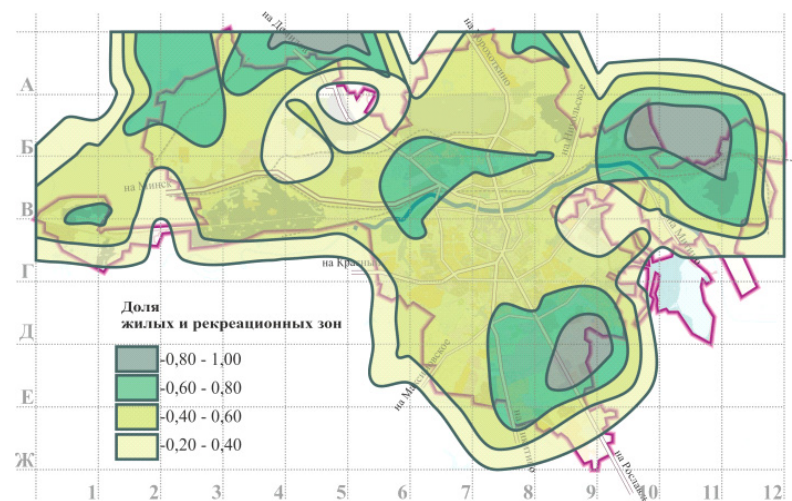

Figure 15. Contour line maps of share of residential and recreational restrictions on use to the total number of restrictions on use for urban zones in Smolensk 
Figure 14 shows that residential and recreational areas permeate the urban planning space. Polynuclear structure of the urban "fabric" is retained, but weakly expressed. Main planning axis is not highlighted. The spatial structure of restrictions on use shares (Figure 15) in general is similar to the spatial structure of urban zones, thus indicating the stability of urban land use zones structure.

Figures 16 and 17 show the results for the city of Tyumen (Tyumen LUDR, 2014).

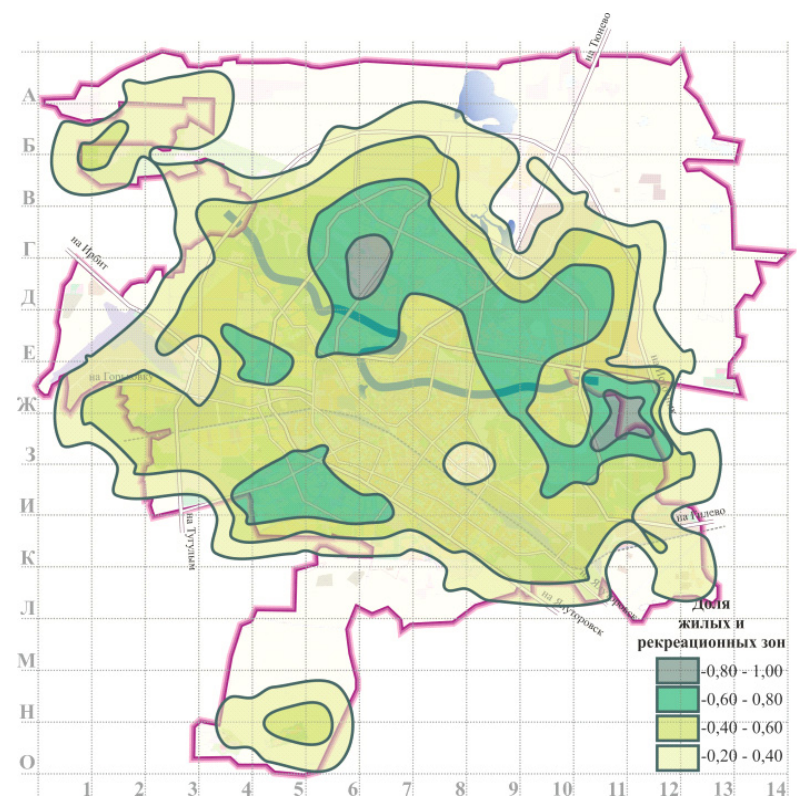

Figure 16. Contour line maps of share of residential and recreational zones to the total number of land use zones for Tyumen

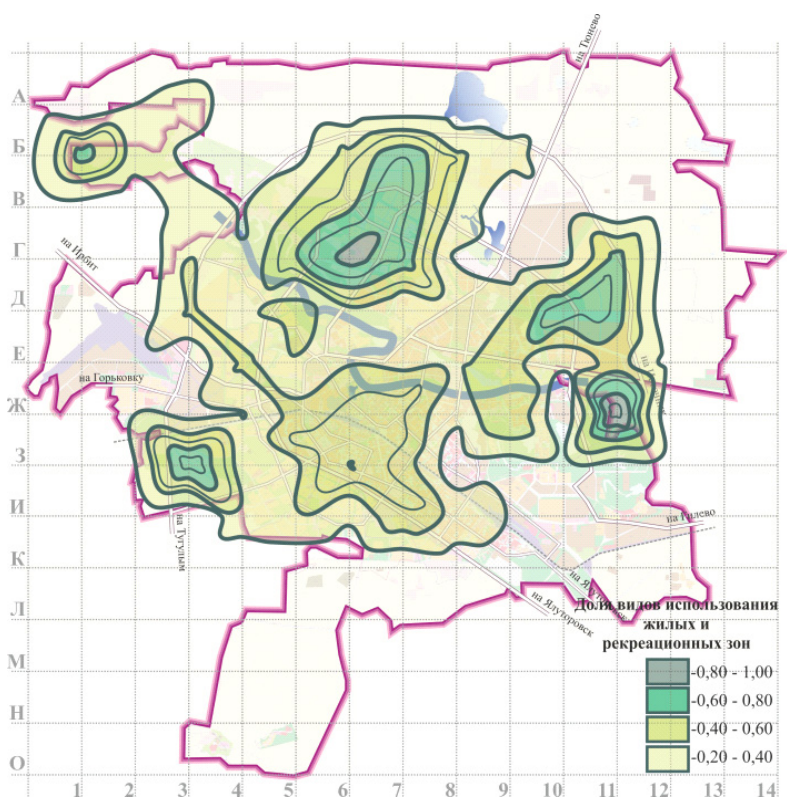

Figure 17. Contour line maps of share of residential and recreational restrictions on use to the total number of restrictions on use for urban zones in Tyumen

Figure 16 shows a contour line map where urban "fabric" formed by the residential and recreational zones permeates all of the urban system planning space. Polynuclear structure of the urban "fabric" s preserved - there are two denser nucleuses. Overall spatial axis is weakly expressed in the direction of "north-west south-east." Contour line map of restrictions on use share of residential and recreational zones restrictions on use - Figure 17 - shows a tendency to form a more differentiated polynuclear area structure.

Figures 6 and 7 show the results for the city of Ufa (Ufa LUDR, 2013). Figures 18 and 19 show that the spatial character of the urban "fabric" for Ufa is qualitatively similar to the spatial distribution of the urban "fabric" for Tyumen. Urban "fabric" formed by the residential and recreational zones permeates all of the urban system planning space. There are several slightly more dense cores. Single spatial axis of residential and recreational areas grouping is not visible, despite the presence of natural communication direction along the river. 


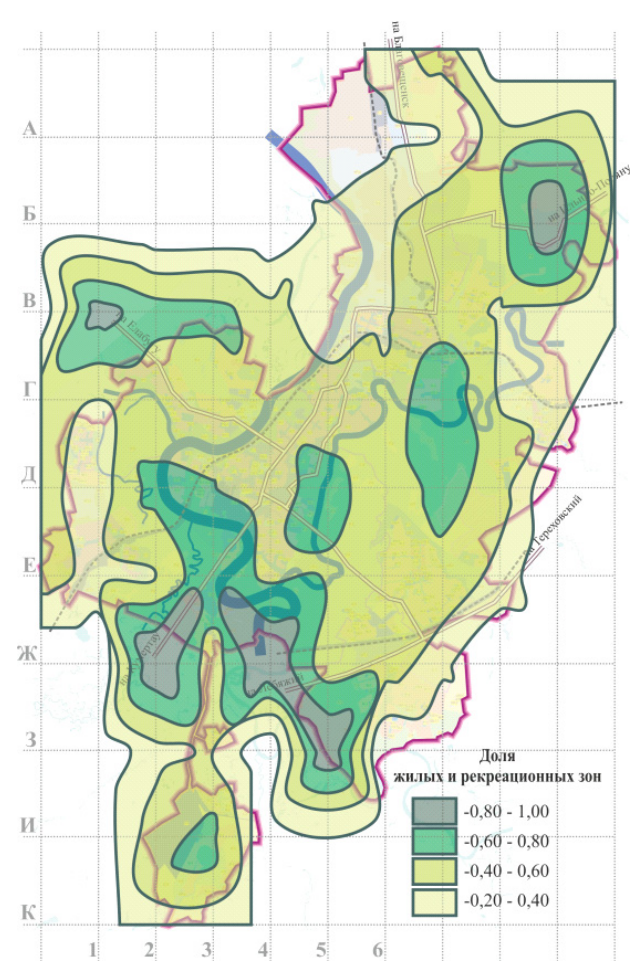

Figure 18. Contour line maps of share of residential and recreational zones to the total number of land use zones for Ufa

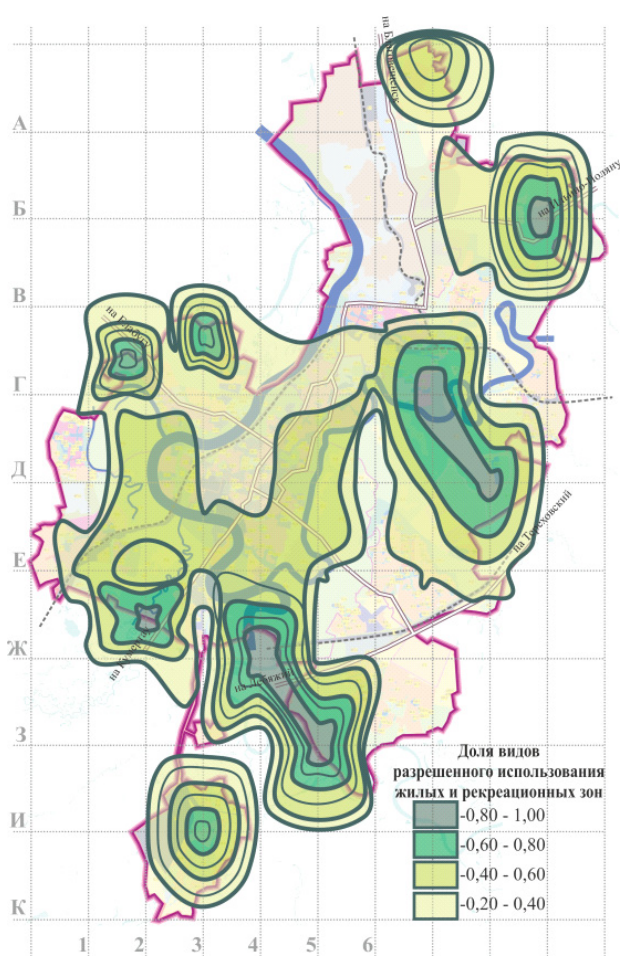

Figure 19. Contour line maps of share of residential and recreational restrictions on use to the total number of restrictions on use for urban zones in Ufa

Contour line map of restrictions on use share of residential and recreational areas - Figure 16 - shows a tendency to form a more differentiated polynuclear structure.

Figures 20 and 21 show the results for the city of Khabarovsk (Khabarovsk LUDR, 2014). The presented maps show that Khabarovsk's "fabric" also permeates all urban planning space. Polynuclear structure of the "fabric" is not visible; the overall planning axis for the residential and recreational areas grouping is not visible, despite the presence of natural communication direction along the river.

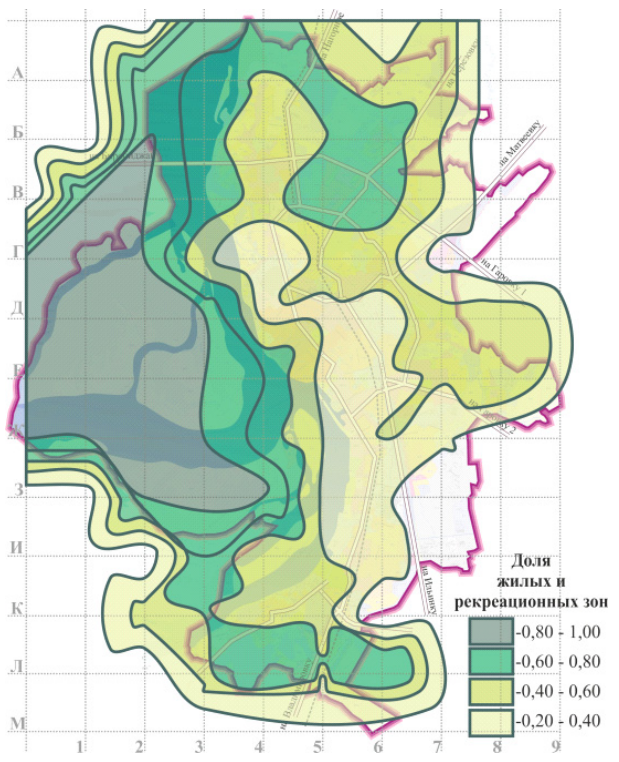

Figure 20. Contour line maps of share of residential and recreational zones to the total number of land use zones for Khabarovsk

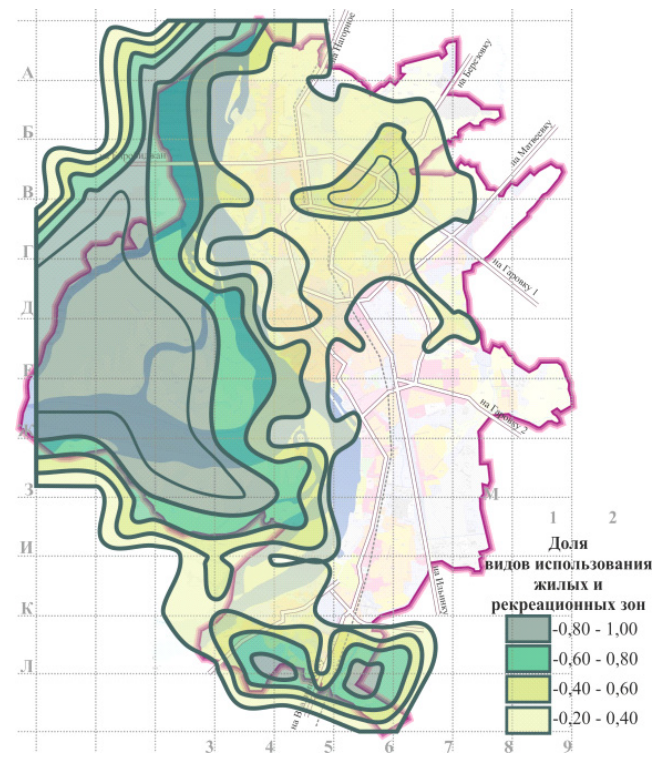

Figure 21. Contour line maps of share of residential and recreational restrictions on use types to the total number of restrictions on use for urban zones in Khabarovsk 


\section{Discussion}

Summary of quantitative results for residential and recreational zones is presented in Table 1.

Table 1. Summary data on the spatial structure of uses share distribution for residential and recreational land use zones

\begin{tabular}{|c|c|c|c|c|}
\hline City & $\begin{array}{c}\text { Single spatial axis } \\
\text { direction }\end{array}$ & $\begin{array}{l}\text { The average city } \\
\text { share of the } \\
\text { residential and } \\
\text { recreational zones } \\
\text { from the total } \\
\text { number of zones }\end{array}$ & $\begin{array}{l}\text { The maximum } \\
\text { share of the } \\
\text { residential and } \\
\text { recreational zones } \\
\text { from the total } \\
\text { number of zones }\end{array}$ & $\begin{array}{l}\text { Maximum value } \\
\text { excess of the } \\
\text { average }\end{array}$ \\
\hline Yekaterinburg & North-south & 0.61 & 1.00 & 1.63 \\
\hline Kaliningrad & $\begin{array}{l}\text { north-west } \\
\text { south-east }\end{array}$ & 0.55 & 1.00 & 1.82 \\
\hline Omsk & $\begin{array}{l}\text { north-west } \\
\text { south-east }\end{array}$ & 0.39 & 1.00 & 2.60 \\
\hline Perm & $\begin{array}{l}\text { West-east } \\
\text { (along the river) }\end{array}$ & 0.42 & 0.86 & 2.10 \\
\hline Ryazan & north south-west & 0.5 & 1.00 & 2.00 \\
\hline Saratov & $\begin{array}{l}\text { north south-west; } \\
\text { centre - north-west }\end{array}$ & 0.58 & 1.00 & 1.71 \\
\hline Smolensk & - & 0.58 & 1.00 & 1.71 \\
\hline Tyumen & - & 0.47 & 1.00 & 2.10 \\
\hline Ufa & - & 0.51 & 1.00 & 1.97 \\
\hline Khabarovsk & - & 0.20 & 0.50 & 2.45 \\
\hline \multicolumn{2}{|c|}{ Average } & 0.48 & 0.94 & 2.01 \\
\hline
\end{tabular}

Based on the table above we can see that the spatial distribution of residential and recreational zones is polycentric while having (or not) a single spatial direction, determining the nature of centres grouping. The average share of residential and recreational zones for different cities is 0.48 , the maximum value of residential and recreational areas share, on average, is 0.94 , and the average excess of the maximum value above average is 2.01. The relative variation range (the difference between the minimum and maximum values, referred to the mean) for the average values is $85 \%$.

Table 2 presents a summary of the spatial distribution of restrictions on use shares specific to residential and recreational zones to the total number of restrictions on use of urban land use zones in the territorial areas.

Table 2. Summary data on the spatial structure of resrtctions on use share distribution for residential and recreation land use zones

\begin{tabular}{llccc}
\hline City & $\begin{array}{c}\text { Single spatial axis } \\
\text { direction }\end{array}$ & $\begin{array}{c}\text { Average share of } \\
\text { restrictions on use } \\
\text { for residential and } \\
\text { recreational zones } \\
\text { from the total } \\
\text { number restrictions }\end{array}$ & $\begin{array}{c}\text { Maximum share of } \\
\text { restrictions on use } \\
\text { for residential and } \\
\text { recreational zones } \\
\text { form the total } \\
\text { number restrictions }\end{array}$ & $\begin{array}{c}\text { Maximum value } \\
\text { excess of the } \\
\text { average }\end{array}$ \\
\hline Yekaterinburg & $\begin{array}{l}\text { North-south } \\
\text { north-west } \\
\text { Kaliningrad }\end{array}$ & 0.51 & 1.00 & \\
South-east & 0.55 & 1.00 & 1.96 \\
Omsk & $\begin{array}{l}\text { north-west } \\
\text { south-east }\end{array}$ & 0.39 & 1.00 & 2.55 \\
Rerm & $\begin{array}{l}\text { West-east } \\
\text { (along the river) } \\
\text { north south west }\end{array}$ & 0.26 & 0.93 & 3.55 \\
\hline
\end{tabular}




\begin{tabular}{lcccc}
\hline Saratov. & $\begin{array}{c}\text { north south-west; } \\
\text { centre - north-west }\end{array}$ & 0.54 & 1.00 & 1.85 \\
Smolensk & - & 0.56 & 1.00 & 1.78 \\
Tyumen & - & 0.32 & 1.00 & 3.08 \\
Ufa & - & 0.25 & 1.00 & 4.00 \\
Khabarovsk & - & 0.26 & 0.84 & 3.20 \\
& Average & 0.41 & 0.98 & 2.60 \\
\hline
\end{tabular}

According to Table 2, the average restrictions on use share for residential and recreational zones is 0.41 , the average value of all maximums is 0.98 , and the average excess of the city average maximum is 2.6. Mean values variation scale $75 \%$ is roughly equivalent to similar characteristics of residential and recreational zones shares. A group of cities with a small proportion of restrictions on use value for residential and recreational zones in relation to the total number of urban land use zones: Omsk, Perm, Ufa, and Khabarovsk, draws attention. Small value of this ratio indicates that there are the territorial areas functional purpose change processes i.e., the process of restructuring the urban "fabric", which should correspond to the frame.

Comparing the results shown in Tables 1 and 2, the features calculated for the share of residential and recreational zones and the shares restrictions on use of residential and recreational zones are quite similar. Summarizing the results, it can be seen that all these cities fall into two distinct groups: the cities with a single spatial axis, and the cities missing spatial direction. For the first group of cities, urban fabric - residential and recreational areas are polynuclear structure. They are grouped in a direction perpendicular to a single axis. For the second group of cities, urban fabric - residential and recreational areas permeates all urban planning space, so polynuclear structure of residential and recreational areas is much less expressed.

The existence of a single spatial axis around which polynuclear urban fabric is further located is the result of a well-known by professional city planners' effect. Thus, V. A. Lavrov and O. K. Kudryavtsev, summing up the experience of the spatial reconstruction for large cities, noted that "the further development will proceed not spontaneously, but by increasing the mechanical bypass concentric areas, over clearly expressed outgoing directions, giving better orientated planning structure" (Kudryavtsev, O. K., \& Lavrov, V. A., 1976). Similarly Bocharov Yu. P. and Kudryavtsev O. K. established the existence of the relationship between the type of structure and geometry of the urban planning system and plan geometry contrast flexible planning structure and closed, static structure. Flexible planning structure, according to Bocharov and Kudryavtsev, is characterized by "growth in predominantly one direction" (Bocharov, Yu. P., \& Kudryavtsev, O. K., 1969). Thus, the effect of the city development in one spatial direction was observed in the 1970's; Lezhava described the modern concept of "linear city" (Lezhava, I., 2012). Further one can see a brief description of the concept of "At the heart of the settlement channels is the transport corridor. It is used for the move of the continuous flow of people, goods, water, energy, and minerals. Channels of their movement are roads, pipelines, various types of conveyors and rail systems. Easy accessibility makes this "channel" area especially suitable for development. This area has a total width of about 10-15 kilometres". Thus, the tendency in the urban fabric organization shall be considered in the context of the expected trends in the transition to the linear city.

\section{Conclusions}

In general, it can be concluded that the study and use of the opportunities contained in the Rules of land use and development open up new possibilities for the study of patterns for using the urban planning space, its structural elements and understanding the laws of urban planning systems development. In particular, studying the spatial characteristics of the residential and recreational planning zones allows studying the structure and properties of the urban fabric as an example of real objects (cities). Studying a sample of real cities, current trends of urban development can be observed.

\section{Acknowledgments}

The authors thank the vice-rector on research of Ural State Academy of Architecture and Arts, Puchkov M.V., and its rector Postnikov S.P. whose support was extremely essential for the publication.

\section{References}

Bocharov, Yu. P., \& Kudryavtsev, O. K. (1969). Infrastructure development in the conditions of group resettlement systems. Obzor. M.. P.87

Brantley, L. (2013). Urban density and climate change: A STIRPAT analysis using city-level data. Journal of Transport Geography, 28, 22-29. 
Gushchin, F. A., Gushchin, A. N., \& Sanok, S. I. (2012). Description of Intensive Development of Territories Based on the Rules Land Use and Development [Electronic resource]. Arkhitekton: News of institutions. Retrieved from http://archvuz.ru/2012_4/19

Gushchin, F. A., Gushchin, A. N., \& Sanok, S. I. (2013). Analysis of the intensity of land development based on land use and development. Industrial zones. MATERIAŁY IX MIĘDZYNARODOWEJ NAUKOWI-PRAKTYCZNEJ KONFERENCJI "PERSPEKTYWICZNE OPRACOWANIA SĄ NAUKĄ I TECHNIKAMI-2013", 07 - 15 listopada 2013 roku. Volume 35. Budownictwo i architektura. p.59-68.

Gushchin, F. A., Gushchin, A. N., \& Sanok, S. I. (2013). Analysis of the intensity of the development of urban areas based on land use and development regulations. Commercial areas. European Applied Sciences, 8, Section 11, 96-108.

Gutnov, A. E. (1984). The evolution of urban planning M.: Stroyizdat. 256 p.

Karathodoroua, N. G., Daniel, J. N., \& Robert, B. (2010). Estimating the effect of urban density on fuel demand. Energy Economics, 32(1), 86-92.

Kudryavtsev, O. K., \& Lavrov, V. A. (1976). Reconstruction of large cities as a continuous process.- in KR. City planning, M.. P.80

Land use and development rule. Approved by the decision of the Khabarovsk City Council as of Feb 25, 2014 No. $876 . \quad$ Khabarovsk Administration. Retrieved from http://dasiz.khabarovskadm.ru/town-planning/rules_of_land_tenure_and_building/

Land use and development rule. Approved by the decision of the Saratov City Council as of Apr 29, 2008 No. 27. Official site of the municipality administration "City of Saratov". Retrieved from http://www.saratovmer.ru/groundusingrules/

Land use and development rule. Approved by the decision of the Tyumen City Council as of Oct 30, 2014 No. 203. Tyumen City Administration. Official portal. Retrieved from http://www.tyumen-city.ru/ekonomika/building/pravila/

Land use and development rule. Approved by the decision of the Yekaterinburg City Council as of Jul 06, 2004 No. 60 / Yekaterinburg official portal. Retrieved from http://www.ekburg.ru/construction/legal-base/

Land use and development rules in Ryazan. Land use and development rules in Ryazan. Approved by the decision of the Ryazan City Council on December 11, 2008. No. 897-I / Official site. Ryazan City Administration. Retrieved from http://admrzn.ru/gorodskaya-sreda/arhitektura-i-stroitelstvo/pravila-zemlepolzovaniya-i-zastrojki-v-ryazani

Land use and development rules in Smolensk. Decision of the 15th session of the Smolensk City Council of IV convocation as of Nov 09, 2010 No. 193. Official site of City Administration of the hero-city of Smolensk. Retrieved from http://www.smoladmin.ru/spravocn/pzz/zem_pr_ogl.html

Land use and development rules of Perm. Approved by the decision of the Perm City Council as of June 26, 2007. No. 143. Perm City Administration. Retrieved from http://www.gorodperm.ru/economic/building-up/landrules/

Land use and development rules. Approved by the Board of city district of Ufa in the Republic of Bashkortostan as of March 20, 2013 No. 15/6. Main Department for Architecture and Urban Development administration of the city of Ufa in the Republic of Bashkortostan. Retrieved from http://gorodufa.ru/?p=48

Land use and development rules. - as of June 01. 2014 / Kaliningrad. City district administration "The City of Kaliningrad". Retrieved from http://www.klgd.ru/construction/gr_documents/pravilo.php

Land use and development rules. Approved by the decision of the Omsk City Council No. 201 as of Dec 10, 2008. Omsk. The official portal of Omsk city administration. Retrieved from http://admomsk.ru/web/guest/city/urban-planning/rules

Lezhava, I. (2012). Linear cities. Domestic notes, 3(48).

McDonald, J. F. (1989). Econometric Studies of Urban Population Density: Survey. Journal of Urban Economics, 26, 361-385.

Smolyar, I. M. (2001). Urban planning as a system: forecasting, programming, design. Works by RAACS. M.: Editorial of URSS. (Theoretical Foundations of Urban Development).

Tsai, Y. H. (2005). Quantifying Urban Form: Compactness versus 'Sprawl'. Urban Studies, 42(1), 141-161. 
Vladimirov, V. V. (1999). Urban planning as a system of scientific knowledg. Works by RAACS. In V. V. Vladimirov, T. F. Svarenskaya, \& Smolyar, I. M. (Eds.), Theoretical Foundations of Urban Development (pp. 35-51).

\section{Copyrights}

Copyright for this article is retained by the author(s), with first publication rights granted to the journal.

This is an open-access article distributed under the terms and conditions of the Creative Commons Attribution license (http://creativecommons.org/licenses/by/3.0/). 